\title{
Infectious Colitis
}

National Cancer Institute

\section{Source}

National Cancer Institute. Infectious Colitis. NCI Thesaurus. Code C78359.

A viral or bacterial infectious process affecting the large intestine. 